Jurnal Keperawatan Silampari

Volume 3, Nomor 2, Juni 2020

e-ISSN: 2581-1975

p-ISSN: 2597-7482

DOI: https://doi.org/10.31539/jks.v3i2.1094

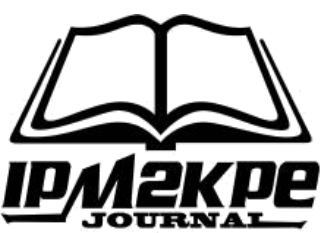

\title{
TERAPI THOUGHT STOPPING, RELAKSASI PROGRESIF DAN PSIKOEDUKASI TERHADAP PENURUNAN ANSIETAS PASIEN GGK YANG MENJALANI HEMODIALISA
}

\author{
Sri Atun Wahyuningsih \\ Akademi Keperawatan Pelni Jakarta \\ atun_pelni@yahoo.com
}

\begin{abstract}
ABSTRAK
Penelitian ini bertujuan untuk menggambarkan manajemen asuhan keperawatan ansietas pada pasien gangguan fisik yang mendapatkan terapi thought stopping, relaksasi progresif dan psikoedukasi di Ruang Hemodialisa lantai 3 Rumah Sakit Pelni Jakarta. Metode dalam penelitian ini menggunakan metode eksperimen. Hasil penelitian terhadap respon pasien ansietas setelah mendapatkan terapi adalah persepsi pasien meluas, respon fisiologis pasien terjadi peningkatan tidur dan makan, respon afektif pasien tidak merasa khawatir dan pasien dapat bersosialisasi. Simpulan, pelaksanaan paket terapi keperawatan yang efektif diberikan pada skala ringan adalah terapi generalis dan terapi spesialis thought stopping, relaksasi progresif dan psikoedukasi dengan hasil kemampuan pasien mengontrol ansietas meningkat serta berdampak positif terhadap caregiver.
\end{abstract}

Kata Kunci: Ansietas, Psikoedukasi, Relaksasi Progresif, Thought Stopping

\section{ABSTRACT}

This study aims to describe the management of anxiety nursing care in physically impaired patients. They receive thought to stop therapy, progressive relaxation, and psychoeducation in the Hemodialysis Room on the 3rd floor of Pelni Hospital in Jakarta. The method in this study uses the experimental process. The results of research on the response of anxiety patients after receiving therapy is a widespread patient perception, the patient's physiological response to an increase in sleep and eating, affective responses of patients do not feel worried, and patients can socialize. The practical implementation of nursing therapy packages provided on a mild scale is generalist therapy and specialist therapy of thought stopping, progressive relaxation, and psychoeducation. The result is that the patient's ability to control anxiety increases and has a positive impact on caregivers.

Keywords: Anxiety, Psychoeducation, Progressive Relaxation, Thought Stopping 


\section{PENDAHULUAN}

Gagal Ginjal Kronis (GGK) atau Chronic Kidney Disease (CKD) merupakan perburukan fungsi ginjal yang lambat, progresif dan irreversible yang menyebabkan ketidakmampuan ginjal untuk membuang produk sisa dan mempertahankan keseimbangan cairan dan elektrolit (Rizqiea et al., 2017).

World Health Organization (2017) melaporkan bahwa pasien yang menderita gagal ginjal kronis telah meningkat $50 \%$ dari tahun sebelumnya, secara global kejadian gagal ginjal kronis lebih dari 500 juta orang dan yang harus menjalani hidup dengan bergantung pada cuci darah (hemodialisa) adalah 1,5 juta orang. Gagal ginjal kronis termasuk 12 penyebab kematian umum di dunia, terhitung 1,1 juta kematian akibat gagal ginjal kronis yang telah meningkat sebanyak 31,7\% sejak tahun 2010 hingga 2015 (Neuen et al., 2017).

Indonesia pada tahun 2018 pasien dengan gagal ginjal kronis meningkat sebanyak 19,3\%. Di Provinsi Bali pada tahun 2018 pasien dengan gagal ginjal kronis meningkat sebanyak 38,7\%. Pada tahun 2016 terdapat 21050 pasien baru yang merupakan pasien yang pertama kali menjalani hemodialisa dan 30554 pasien aktif menjalani hemodialisa secara rutin dan masih hidup hingga 31 Desember 2015. Di Provinsi Bali penderita gagal ginjal kronis adalah 0,2\% atau berjumlah 78.000 pasien. Dinas Kesehatan Provinsi Bali melaporkan pada tahun 2015 terdapat 1.572 kasus penyakit gagal ginjal kronis di Bali. Di kabupaten Gianyar terdapat 0,2\% pasien dengan gagal ginjal kronis (Riskesdas, 2018).

Hemodialisis (HD) merupakan terapi pengganti dari fungsi ginjal yang dilakukan 2-3 kali seminggu, dengan rentang waktu tiap tindakan hemodialisa adalah 4-5 jam, yang bertujuan untuk mengeluarkan sisa metabolisme protein dan untuk mengoreksi gangguan keseimbangan cairan dan elektrolit (Rini, Suryandari, 2019; Wijaya, Padila, 2019).

Hal ini didukung oleh hasil penelitian tentang pemberian terapi psikoedukasi terbukti efektif menurunkan tingkat stres, cemas dan depresi pada penderita TB paru. Pada penelitian ini juga dapat disimpulkan bahwa dalam memberikan terapi psikoedukasi haruslah mempertimbangkan latar belakang pendidikan dari penderita. Pada umumnya mereka yang menderita penderita TB paru adalah mereka yang berlatar pendidikan rendah dan miskin, karena itu psikoedukasi baik psief maupun aktif hasus menggunakan Bahasa awam. Peneliti sudah menyeseuaikannya bukan menggunakan Bahasa ilmiah (Suryani et al., 2016). Penelitian ini juga didukung oleh Siswoyo, Holil (2016) dalam pemberian terapi psikoedukasi pada keluarga yang mengalami kecemasan dapat meningkatkan pengetahuan dan pemberdayaan keluarga dalam merawat anggota keluarga yang menderita katarak. FPE terdiri dari kegiatan yang dapat meningkatkan fungsi adaptif keluarga dan meningkatkan ketrampilan mekanisme koping yang positif (Widiyati, 2016; Wijaya, Padila, 2019).

Penelitian lain oleh terapi thought stopping dan relaksasi progresif dapat menurunkan ansietas sedang ke ansietas ringan. Penelitian Widarti menghasilkan penurunan tingkat ansietas pada siswa yang akan melakukan ujian. Terapi relaksasi progresif yang diberikan terhadap responden yaitu mahasiswa yang akan mengikuti uji kompetensi mengalami penurunan ansietas sehingga responden dapat mengikuti ujian dengan lancar dan fokus (Hidayat, 2018). Hal ini menunjukan bahwa terapi relaksasi progresif sangat berguna untuk menurunkan ansietas. Terapi relaksasi progresif merangsang pengeluaran zat-zat kimia endorphin dan ensephalin serta merangsang signal otak yang menyebabkan otot rileks dan meningkatkan aliran darah ke otak. 
Penelitian sebelumnya sudah ada tapi hanya menghubungkan antar 1 variabel saja, namun penelitian ini melihat ketiga terapi ini yaitu terapi thought stopping, relaksasi progresif dan psikoedukasi terhadap penurunan ansietas dalam satu waktu.

\section{METODE PENELITIAN}

Penelitian ini merupakan penelitian eksperimen dimana subyek penelitiannya adalah seluruh pasien gagal ginjal kronik yang sedang menjalani hemodialisa di Ruang Hemodialisa lantai 3 RS Pelni Jakarta, karena penelitian ini adalah melakukan inrervensi ke seluruh pasien. Pendekatan yang dilakukan adalah mengkaji seluruh pasien yang ada di ruang Hemodialisa lantai 3 mulai hari Senin sampai Rabu karena jadwal hemodialisa pada pasien tersebut dua kali seminggu, bila Senin dan Kamis, Selasa dengan Jum'at serta Rabu dengan Sabtu. Semua pasien dilakukan pengkajian mulai dari data demografi dan pengkajian tingkat ansietas. Saat pelaksanaan pengkajian peneliti dibantu oleh perawat ruangan dan menggunakan tabel yang sudah ditentukan untuk mempermudah mengklasifikasi tingkat ansietas pada pasien tersebut yang sebelumnya perawat sudah diberikan penjelasan oleh peneliti.

Dalam penelitian ini didapatkan 91 pasien yang fokus mendapatkan terapi thought stopping dan terapi relaksasi progresif serta psikoedukasi. Hasil manajemen kasus pada pasien ansietas yang diberikan terapi thought stopping, relaksasi progresif dan psikoedukasi. Pemberian terapi berdasarkan paket yang telah dibuat oleh penulis terdiri dari tiga paket yaitu paket pertama terapi thought stopping, paket kedua terdiri dari terapi thought stopping dan relaksasi progresif, paket ketiga terdiri dari terapi thought stopping, relaksasi progresif dan psikoedukasi. Pemberian terapi paket satu diberikan kepada 91 pasien kemudian paket kedua kepada 20 pasien, dan paket ketiga diberikan kepada 31 pasien.

\section{HASIL PENELITIAN}

Tabel. 1

Distribusi Karakteristik Pasien Ansietas

$(n=91)$

\begin{tabular}{|c|c|c|c|}
\hline No & Karakteristik & Jumlah & $\%$ \\
\hline \multirow[t]{4}{*}{1} & Usia & & \\
\hline & a. $<20$ tahun & 2 & 2.20 \\
\hline & b. $21-40$ tahun & 10 & 10.99 \\
\hline & c. $>41$ tahun & 79 & 86.81 \\
\hline \multirow[t]{3}{*}{2} & Jenis kelamin & & \\
\hline & a. Laki-laki & 51 & 56,04 \\
\hline & b. Perempuan & 40 & 43.96 \\
\hline \multirow[t]{5}{*}{3} & Pendidikan & & \\
\hline & a. Rendah (SD/tak tamat) & 3 & 3.30 \\
\hline & b. Menengah (SMP) & 22 & 24.18 \\
\hline & c. Tinggi (SMA) & 52 & 57.14 \\
\hline & d. PT & 19 & 20.88 \\
\hline \multirow[t]{3}{*}{4} & Pekerjaan & & \\
\hline & a. Bekerja & 42 & 46.15 \\
\hline & b. Tidak bekerja & 49 & 53.85 \\
\hline
\end{tabular}


5 Status perkawinan
a. Belum menikah
b. Menikah
c. Duda/Janda

Berdasarkan tabel 1 menunjukkan mayoritas pasien berada dalam rentang usia dewasa yaitu 89 orang $(97.80 \%)$ dan berjenis kelamin laki-laki 51 (56,04\%). Mayoritas pasien memiliki latar belakang pendidikan Sekolah Menengah Atas (SMA) yaitu 52 orang (57.14\%), tidak bekerja (53.83\%), dan status perkawinan menikah $(81,32 \%)$.

Tabel.2

Distribusi Stresor Predisposisi

pada Pasien Ansietas ( $\mathrm{n}=91$ )

\begin{tabular}{llcc}
\hline No & Stresor Predisposisi & Jumlah & $\%$ \\
\hline 1 & Biologis & 40 & 43.96 \\
& Penyakit DM & 9 & 9.89 \\
& Penyakit ginjal & 31 & 34.07 \\
& Hipertensi & 11 & 12.09 \\
\hline & Nepropatik toksik & & \\
\hline 2 & Psikologis & 91 & 100 \\
& Sedih memikirkan penyakitnya & 91 & 100 \\
& Khawatir dengan penyakitnya & 35 & 38.46 \\
& Merasa gagal & & \\
\hline 3 & Sosial kultural & 25 & 27.47 \\
& Pendidikan rendah & 49 & 53.85 \\
& Pekerjaan kurang memadai & 44 & 48.35 \\
\hline
\end{tabular}

Berdasarkan tabel 2 menunjukkan bahwa pada stresor predisposisi biologis semua pasien $(100 \%)$ karena penyakit kronis. Semua pasien mengalami kesedihan $(100 \%)$ pada aspek psikologis, sehingga pasien merasa sedih dan khawatir. Stresor predisposisi sosial kultural pada pekerjaan yang tidak memadai sebanyak 48,35\%.

Tabel. 3

Distribusi Respon terhadap Stresor pada Pasien Ansietas ( $\mathrm{n}=91$ )

\begin{tabular}{|c|c|c|c|}
\hline No & Respon terhadap Stressor & Jumlah & $\%$ \\
\hline & \multicolumn{3}{|l|}{ Respon Kognitif } \\
\hline & Lapang Persepsi Menurun & 45 & 49.45 \\
\hline & Hambatan berfikir & 67 & 73.63 \\
\hline & Sulit mengambil keputusan & 45 & 49.45 \\
\hline & Menyalahkan orang lain & 43 & 47.25 \\
\hline & \multicolumn{3}{|l|}{ Respon Fisiologis } \\
\hline & Tekanan darah meningkat & 80 & 87.91 \\
\hline & Gangguan pola tidur & 76 & 83.52 \\
\hline & Gangguan pola makan & 77 & 84.62 \\
\hline & Pusing & 78 & 85.71 \\
\hline
\end{tabular}




\begin{tabular}{lll}
\hline Respon Afektif & & \\
Sedih & 69 & 75.82 \\
Khawatir & 79 & 86.81 \\
Bingung & 44 & 48.35 \\
Tidak berdaya & 69 & 75.82 \\
\hline Respon Perilaku & & 87.91 \\
Produktivitas menurun & 80 & 59.34 \\
Bicara cepat & 54 & 37.36 \\
Gerakan tidak terarah & 34 & 53.85 \\
Respon Sosial & & 48.35 \\
Masih dapat bersosialisasi & 49 & 8.79 \\
Jarang bersosialisasi & 44 & \\
Menarik diri & 8 & \\
\hline
\end{tabular}

Berdasarkan tabel 3 respon kognitif pada pasien yang mengalami ansietas sebagian besar 73,63\% pasien mengalami hambatan berpikir. Respon fisiologis pasien sebagian besar tekanan darah meningkat, mengalami gangguan tidur, gangguan pila makan dan mengalami pusing. Respon afektif sebagian besar pasien merasa khawatir sebanyak 79 pasien $(86,81 \%)$ dan mengalami sedih dan bingung. Pada respon perilaku pada pasien ansietas terdapat produktivitas menurun sebanyak 80 (87,91). Respon sosial pada pasien ansietas ditemukan sebagian jarang bersosialisasi sebanyak 44 pasien $(48,35 \%)$.

Tabel. 4

Distribusi Kemampuan Mengatasi Masalah pada Pasien Ansietas ( $\mathrm{n}=91)$

\begin{tabular}{|c|c|c|c|}
\hline No & Kemampuan & Jumlah & $\%$ \\
\hline \multirow[t]{4}{*}{1} & Kemampuan personal & & \\
\hline & $\begin{array}{l}\text { a. Pasien mampu mengidentifikasi tanda dan gejala } \\
\text { ansietas }\end{array}$ & 80 & 87.91 \\
\hline & b. Pasien mampu mengontrol emosi & 68 & 74.73 \\
\hline & c. Pasien mampu merubah pikiran negatif & 45 & 49.45 \\
\hline \multirow[t]{3}{*}{2} & Keyakinan positif & & \\
\hline & a. Yakin dengan kesembuhan & 66 & 75.53 \\
\hline & b. Yakin terhadap pelayanan kesehatan & 88 & 96.70 \\
\hline \multirow[t]{6}{*}{3} & Dukungan keluarga & & \\
\hline & a. Mampu mengenal masalah ansietas & 77 & 84.62 \\
\hline & b. Mampu memutuskan & 81 & 89.01 \\
\hline & c. Mampu merawat pasien ansietas & 76 & 83.52 \\
\hline & d. Mampu mempertahankan lingkungan yang tenang & 65 & 71.43 \\
\hline & e. Mampu menggunakan fasilitas kesehatan & 86 & 94.51 \\
\hline
\end{tabular}

Berdasarkan tabel 4 maka dapat dijelaskan bahwa kemampuan personal pasien sebagian besar pasien masih mampu mengidentifikasi ansietas sebanyak 80 pasien $(87.91,21 \%)$. Keyakinan positif pasien ansietas didapatkan sebagian besar $96,70 \%$ percaya terhadap pelayanan kesehatan. Dukungan sosial dari keluarga terhadap memanfaatkan fasilitas kesehatan sebanyak 94,51\%. 
Tabel. 5

Distribusi Hasil Evaluasi terhadap Respon pada Pasien Ansietas Setelah Mendapatkan Tindakan Keperawatan Paket 1 (Terapi Thought Stopping) ( $\mathrm{n}=91)$

\begin{tabular}{|c|c|c|c|c|c|}
\hline No & Respon Terhadap Stresor & Pre & $\%$ & Post & $\%$ \\
\hline 1 & $\begin{array}{l}\text { Respon Kognitif } \\
\text { a. Lapang persepsi menurun } \\
\text { b. Hambatan berfikir } \\
\text { c. Sulit mengambil keputusan } \\
\text { d. Menyalahkan orang lain }\end{array}$ & $\begin{array}{l}45 \\
67 \\
45 \\
43\end{array}$ & $\begin{array}{l}49.45 \\
73.63 \\
49.45 \\
47.25\end{array}$ & $\begin{array}{l}25 \\
34 \\
22 \\
23\end{array}$ & $\begin{array}{l}27.47 \\
37.36 \\
24.18 \\
25.27\end{array}$ \\
\hline 2 & $\begin{array}{l}\text { Respon Fisiologis } \\
\text { a. Tekanan darah meningkat } \\
\text { b. Gangguan pola tidur } \\
\text { c. Gangguan pola makan } \\
\text { d. Pusing }\end{array}$ & $\begin{array}{l}80 \\
76 \\
77 \\
78\end{array}$ & $\begin{array}{l}87.91 \\
83.52 \\
84.62 \\
85.71\end{array}$ & $\begin{array}{l}60 \\
45 \\
33 \\
23\end{array}$ & $\begin{array}{l}65.93 \\
56.04 \\
48.35 \\
48.35\end{array}$ \\
\hline 3 & $\begin{array}{l}\text { Respon Afektif/Psikologis } \\
\text { a. Sedih } \\
\text { b. Khawatir } \\
\text { c. Bingung } \\
\text { d. Tidak berdaya }\end{array}$ & $\begin{array}{l}69 \\
79 \\
44 \\
69\end{array}$ & $\begin{array}{l}75.82 \\
86.81 \\
48.35 \\
75.82\end{array}$ & $\begin{array}{l}43 \\
41 \\
23 \\
36\end{array}$ & $\begin{array}{l}47.25 \\
45.05 \\
25.27 \\
39.56\end{array}$ \\
\hline 4 & $\begin{array}{l}\text { Respon Perilaku } \\
\text { a. Produktivitas menurun } \\
\text { b. Bicara cepat } \\
\text { c. Gerakan tidak terarah }\end{array}$ & $\begin{array}{l}80 \\
54 \\
34\end{array}$ & $\begin{array}{l}87.91 \\
59.34 \\
37.36 \\
\end{array}$ & $\begin{array}{l}54 \\
21 \\
21\end{array}$ & $\begin{array}{l}59.34 \\
23.08 \\
23.08 \\
\end{array}$ \\
\hline 5 & $\begin{array}{l}\text { Respon Sosial } \\
\text { a. Masih dapat bersosialisasi } \\
\text { b. Jarang bersosialisasi } \\
\text { c. Menarik diri }\end{array}$ & $\begin{array}{c}49 \\
44 \\
8\end{array}$ & $\begin{array}{l}33.93 \\
35.71 \\
14.28\end{array}$ & $\begin{array}{c}56 \\
22 \\
6\end{array}$ & $\begin{array}{c}61.54 \\
24.18 \\
6.59\end{array}$ \\
\hline
\end{tabular}

Berdasarkan tabel 5 di atas dapat dijelaskan bahwa setelah dilakukan tindakan perawatan pada pasien ansietas dengan memberikan terapi generalis dan spesialis paket 1 yaitu terapi thought stopping maka terjadi penurunan gejala kognitif yaitu sulit mengambil keputusan dari 49,45\% menjadi $24,18 \%$. Respon fisiologis pasien yaitu gangguan tidur dari $83,52 \%$ menjadi $48,35 \%$. Respon psikologis yaitu merasa khawatir dari $86,81 \%$ menjadi $45,05 \%$, gejala perilaku bicara cepat $59,34 \%$ menjadi $23,08 \%$ dan sosial yaitu jarang bersosialisasi dari 48,35\% menjadi $24,18 \%$.

Tabel. 6

Distribusi Kemampuan Mengatasi Masalah pada Pasien Ansietas Setelah Diberikan Tindakan Keperawatan Paket 1 (Terapi Thought Stopping) $(\mathrm{n}=91)$

\begin{tabular}{llcccc}
\hline No & \multicolumn{1}{c}{ Kemampuan } & Pre & $\%$ & Post & $\%$ \\
\hline 1 & Kemampuan personal & & & & \\
& a. Pasien mampu mengidentifikasi ansietas & 80 & 87.91 & 87 & 95.60 \\
& b. Pasien mampu mengontrol emosi & 68 & 74.73 & 70 & 76.92 \\
& c. Pasien mampu merubah pikiran negatif & 45 & 49.45 & 56 & 61.54 \\
\hline 2 & Keyakinan positif & 66 & 72.53 & 73 & 80.22 \\
& a. Yakin dengan kesembuhan & 88 & 96.70 & 90 & 98.90 \\
b. Yakin terhadap pelayanan kesehatan & & & &
\end{tabular}




\begin{tabular}{lllll}
\hline 3 Dukungan sosial & & & & \\
a. Mampu mengenal ansietas & 77 & 84.62 & 85 & 93.41 \\
b. Mampu memutuskan & 81 & 89.01 & 87 & 95.60 \\
c. Mampu merawat & 76 & 83.52 & 85 & 93.41 \\
d. Mampu mempertahankan lingkungan & 65 & 71.43 & 78 & 85.71 \\
e. Mampu menggunakan fasilitas kesehatan & 86 & 94.51 & 90 & 98.90 \\
\hline
\end{tabular}

Berdasarkan tabel 6 dapat dijelaskan kemampuan pasien setelah diberikan terapi paket 1 (terapi thought stopping) didapatkan peningkatan yang paling dominan terdapat pada kemampuan pasien dalam mengidentifikasi ansietas dari 87,91\% menjadi 95,60\%, keyakinan positif bahwa pasien meyakini kesembuhan dari $72,53 \%$ menjadi $80,22 \%$. Dukungan sosial pada keluarga mampu mempertahankan lingkungan dari 71,43\% menjadi $85,71 \%$ dengan cara keluarga memodifikasi lingkungan yang kondusif. Lingkungan kondusif pada keluarga yang harmonis, lingkungan yang saling mendukung dan penerimaan pasien di lingkungan masyarakat.

Tabel. 7

Distribusi Hasil Evaluasi terhadap Respon pada Pasien Ansietas Setelah Mendapatkan Tindakan Keperawatan Paket 2 (Terapi Thought Stopping, Relaxsasi Progressive) $(\mathrm{n}=20)$

\begin{tabular}{|c|c|c|c|c|c|}
\hline No & Respon Terhadap Stresor & Pre & $\%$ & Post & $\%$ \\
\hline \multirow{5}{*}{1} & Respon Kognitif & & & & \\
\hline & a. Lapang persepsi menurun & 15 & 75.00 & 10 & 50.00 \\
\hline & b. Hambatan berfikir & 10 & 50.00 & 6 & 30.00 \\
\hline & c. Sulit mengambil keputusan & 13 & 65.00 & 8 & 40.00 \\
\hline & d. Menyalahkan orang lain & 15 & 75.00 & 10 & 50.00 \\
\hline \multirow{5}{*}{2} & Respon Fisiologis & & & & \\
\hline & Tekanan darah meningkat & 19 & 95.00 & 18 & 90.00 \\
\hline & b. Gangguan pola tidur & 18 & 90.00 & 12 & 60.00 \\
\hline & c. Gangguan pola makan & 16 & 80.00 & 11 & 55.00 \\
\hline & d. Pusing & 17 & 85.00 & 13 & 65.00 \\
\hline \multirow{5}{*}{3} & Respon Afektif/Psikologis & & & & \\
\hline & a. Sedih & 16 & 80.00 & 11 & 55.00 \\
\hline & b. Khawatir & 15 & 75.00 & 12 & 60.00 \\
\hline & c. Bingung & 13 & 65.00 & 11 & 55.00 \\
\hline & d. Tidak berdaya & 15 & 75.00 & 11 & 55.00 \\
\hline \multirow{4}{*}{4} & Respon Perilaku & & & & \\
\hline & a. Produktivitas menurun & 16 & 80.00 & 12 & 60.00 \\
\hline & b. Bicara cepat & 14 & 70.00 & 9 & 45.00 \\
\hline & c. Gerakan tidak terarah & 15 & 75.00 & 10 & 50.00 \\
\hline \multirow{4}{*}{5} & Respon Sosial & & & & \\
\hline & a. Masih dapat bersosialisasi & 15 & 75.00 & 16 & 80.00 \\
\hline & b. Jarang bersosialisasi & 12 & 60.00 & 8 & 40.00 \\
\hline & c. Menarik diri & 9 & 45.00 & 4 & 20.00 \\
\hline
\end{tabular}

Berdasarkan tabel 7 di atas dapat dijelaskan bahwa setelah dilakukan tindakan perawatan pada pasien ansietas dengan memberikan terapi generalis dan spesialis paket 2 yaitu terapi thought stopping dan relaxasi progressive) maka terjadi penurunan gejala kognitif yaitu hambatan berpikir dari 50\% menjadi 30\%. Respon fisiologis pasien yaitu gangguan tidur dari $90 \%$ menjadi $60 \%$. Respon psikologis yaitu merasa khawatir dari $75 \%$ 
menjadi $60 \%$, gejala perilaku bicara sepat menurun dari $70 \%$ menjadi $45 \%$ dan sosial yaitu menarik diri dari $45 \%$ menjadi $20 \%$.

Tabel. 8

Distribusi Kemampuan Mengatasi Masalah pada Pasien Ansietas Setelah Diberikan Tindakan

Keperawatan Paket 3 (Terapi Thought Stopping, Relaxsasi Progressive dan PSE ) ( $\mathrm{n}=31$ )

\begin{tabular}{|c|c|c|c|c|c|}
\hline No & Kemampuan & Pre & $\%$ & Post & $\%$ \\
\hline \multirow[t]{4}{*}{1} & Kemampuan personal & & & & \\
\hline & $\begin{array}{l}\text { a. Pasien mampu mengidentifikasi } \\
\text { ansietas }\end{array}$ & 22 & 70.97 & 29 & 93.55 \\
\hline & b. Pasien mampu mengontrol emosi & 15 & 48.39 & 25 & 80.65 \\
\hline & $\begin{array}{ll}\text { c. Pasien mampu merubah pikiran } \\
\text { negatif }\end{array}$ & 16 & 51.61 & 27 & 87.10 \\
\hline \multirow[t]{3}{*}{2} & Keyakinan positif & & & & \\
\hline & a. Yakin dengan kesembuhan & 23 & 74.19 & 24 & 77.42 \\
\hline & b. Yakin terhadap pelayanan & 22 & 70.97 & 31 & 100 \\
\hline \multirow[t]{6}{*}{3} & Dukungan sosial & & & & \\
\hline & a. Mampu mengenal ansietas & 23 & 74.19 & 29 & 93.55 \\
\hline & b. Mampu memutuskan & 20 & 64.52 & 28 & 90.32 \\
\hline & c. Mampu merawat & 23 & 74.19 & 26 & 83.87 \\
\hline & $\begin{array}{lll}\text { d. } & \begin{array}{l}\text { Mampu mempertahankan } \\
\text { lingkungan }\end{array} & \end{array}$ & 21 & 67.74 & 28 & 90.32 \\
\hline & $\begin{array}{l}\text { Mampu menggunakan fasilitas } \\
\text { kesehatan }\end{array}$ & 29 & 93.55 & 31 & 100 \\
\hline
\end{tabular}

Berdasarkan tabel 8 dapat dijelaskan kemampuan pasien setelah diberikan terapi paket 3 (terapi thought stopping, relaxsasi progressive dan PSE) didapatkan peningkatan yang paling dominan terdapat pada kemampuan pasien dalam mengidentifikasi ansietas dari 70,97\% menjadi $93,55 \%$, keyakinan positif bahwa pasien meyakini kesembuhan dari $74,19 \%$ menjadi $93,55 \%$. Dukungan sosial pada keluarga mampu menggunakan fasilitas kesehatan dari 93,55\% menjadi 100\% dengan cara keluarga memodifikasi lingkungan yang kondusif. Lingkungan kondusif pada keluarga yang harmonis, antar anggota keluarga saling menyayangi, lingkungan yang saling mendukung dan penerimaan pasien di lingkungan masyarakat.

\section{PEMBAHASAN}

\section{Karakteristik Responden}

Pasien yang dikelola dengan masalah ansietas sebagian besar berusia lebih dari 40 tahun dan sebagian berusia 21-40 tahun. Menggolongkan usia lebih dari 40 tahun ke dalam usia dewasa tengah dan usia 21- 40 tahun pada tahapan usia dewasa awal. Tahap usia dewasa merupakan tahapan dimana individu mampu terlibat dalam kehidupan keluarga, masyarakat, pekerjaan. Salah satu tugas perkembangan yang harus dicapai pada tahapan ini adalah membimbing dan menyiapkan generasi di bawah usianya secara arif dan bijaksana. Sedangkan usia dewasa awal dicirikan dengankemampuan berinteraksi akrab dengan orang lain terutama lawan jenis dan memiliki pekerjaan. Tugas perkembangan pada usia dewasa 
awal ini adalah membentuk keluarga baru. Tahapan usia dewasa awal dan dewasa tengah merupakan tahapan dimana individu mempunyai tanggung jawab fungsi keluarga.

Sejalan dengan penelitian Livana et al., (2019) karakteristik respoden keluarga psien hemodialisis sebagian besar berusia 26-60 tahun yaitu sebanyak 45 (75\%) responden. Sedangkan karakteristik pasien hemodialisis juga sama sebagian besar responden berusia 26-60 tahun yaitu sebanyak 44 (73,3\%) responden.

Pada penelitian ini yang teridentifikasi mengalami ansietas sebagian besar adalah laki-laki $(56,04 \%)$. menyatakan pada laki-laki banyak mempunyai stressor khususnya harus bertanggung jawab terhadap keluarga.

Sejalan dengan penelitian Kamil et al., (2018) responden kebanyakan adalah berjenis kelamin laki-laki dengan jumlah 107 responden (58,5\%), sedangkan perempuan sebanyak 76 responden (41,5\%). Hasil penelitian Widiyati (2016) menyatakan adanya hubungan jenis kelamin terhadap kecemasan pasien gagal ginjal kronik yang sedang menjalani hemodialisa.

\section{Pengaruh Terapi Thought Stopping, Relaksasi Progresif dan Psikoedukasi}

Hasil penelitian yang ditemukan adalah setelah diberikan dua terapi kombinasi masih ada respon terhadap stresor yang belum hilang. Respon kognitif yang masih ada adalah lapang persepsi, hambatan berfikir, sulit mengambil keputusan. Respon fisiologis terhadap gangguan pola tidur, gangguan pola makan dan pasien masih merasakan pusing sedangkan respon afektif yang masih ada yaitu pasien masih merasa sedih, khawatir, bingung dan merasa tidak berdaya. Respon perilaku dan respon sosial masih ada pada gangguan produktivitas, bicara cepat, pasien masih mengungkapkan jarang bersosialisasi. Perlunya terapi lain untuk melengkapi sehingga pasien dan keluarga mampu mengatasi ansietas.

Hasil penerapan terapi relaksasi otot progressif pada klien ansiteas terlihat pada tanda dan gejala. Perubahan hasil ini senada dengan yang menyatakan bahwa progressive muscle relaxation merupakan salah satu terpai yang membantu tehnik pengelolaan diri yang didasarkan pada cara kerja sistem saraf simpatis dan parasimpatis. Relaksasi otot akan menghambat jalur yang memicu ansietas dengan cara mengaktivasi sistem saraf parasimpatis dan manipulasi hipotalamus melalui pemusatan pikiran atau memperkuat sikap positif sehingga rangsangan stresor terhadap hipotalamus menjadi minimal. Kondisi tersebut membuat klien yang awalnya menunjukkan perilaku lemah dan tergantung pada orang lain akan merasa lebih nyaman dan lebih rileks dalam melakukan sesuatu. Seperti diketahui relaksasi otot progressif merupakan bagian dari terapi perilaku. Teknik terapi perilaku ini dilakukan untuk melakukan distraksi dengan harapan dapat merubah perilaku klien dari yang maladaptif menjadi adaptif dalam menghadapi stresor. Selain membantu menurunkan gejala fisik dan perilaku terapi ini juga berpengaruh pada kognitif individu yang mengalami ansietas (Syisnawati et al., 2017).

Terapi spesialis keluarga yang dirancang berdasarkan sumber koping yang dimiliki oleh pasien adalah terapi psikoedukasi keluarga. Terapi ini dirancang berdasarkan pengkajian sumber koping pada faktor dukungan sosial. Indikasi pemberian terapi psikoedukasi keluarga ini adalah keterbatasan dukungan keluarga yang disebabkan oleh kurangnya pengetahuan keluarga dalam menghadapi stresor. Terapi psikoedukasi keluarga dapat diberikan pada skala ansietas ringan. Alasan pemberian psikoedukasi pada skala ansietas ringan adalah karena terapi psikoedukasi memerlukan kemampuan kognitif yang 
luas dalam proses belajar, pada skala ansietas ringan kemampuan belajar keluarga masih baik. Dampak dari pemberian terapi psikoedukasi ini adalah kemampuan keluarga dalam memanajemen konflik yang terjadi akibat dari adanya anggota keluarga yang dirawat.

Analisa yang didapat kombinasi terapi thought stopping, relaksasi progresif dan psikoedukasi keluarga sangat efektif diberikan pada pasien ansietas. Pasien dapat merubah pikiran yang negatif dengan cara melakukan gerakan meregangkan dan melemaskan pada sejumlah otot sehingga aliran darah pada semua sistem menjadi lancar dan pada akhirnya akan mengurangi gangguan fisiologis pasien. Dukungan keluarga akan membantu mempercepat penyembuhan pasien, dengan psikoedukasi keluarga akan mampu mengatasi ansietas baik ke pasien maupun ke keluarga.

Berdasarkan evaluasi dapat dianalisa bahwa seluruh terapi yang diberikan berfokus untuk menyelesaikan sumber koping khususnya kemampuan personal dan keyakinan positif. Seluruh paket menunjukkan adanya peningkatan kemampuan mengontrol ansietas dan menurunkan skala ansietas. Dari 3 terapi keperawatan yang paling efektif dilakukan adalah paket ketiga karena telah mencakup seluruh terapi pada seluruh skala ansietas. Pada paket pertama terapi yang diberikan meliputi terapi terhadap kemampuan kognitif, afektif, fisiologis, perilaku dan sosial. Namun demikian paket terapi keperawatan seharusnya dapat dilengkapi dengan terapi untuk membantu menyelesaikan kebutuhan sumber koping khususnya dukungan sosial berupa terapi suportif dan self help group. Terapi suportif dan SHG ini diharapkan dapat meningkatkan sustainability terhadap kemampuan pasien.

Upaya yang dapat dilakukan dalam mengatasi kendala belum membudayanya perawat ruangan untuk melakukan terapi generalis adalah dengan menggunakan pola konsultan di unit pelayanan umum. Adanya penjenjangan dalam manajemen kasus dengan pola konsultan akan meningkatkan kolaborasi antar perawat di seluruh level pendidikan. Perawat konsultan jiwa minimal ditempatkan satu di unit pelayanan umum sehingga dapat meningkatkan mutu pelayanan psikososial baik terhadap pasien maupun keluarga.

Hasil penelitian Hidayat (2018) pengukuran tingkat kecemasan menggunakan skala HARS (Hamilton Anxienty Rating Scale) Analisis hasil penelitian terdiri atas analisis univariat dan bivariat, dengan menggunakan persentase, uji dependen t-test dan uji independen $\mathrm{t}$ test. Hasil penelitian menunjukan terdapat penurunan tingkat kecemasan yang bermakna pada kelompok intervensi setelah dilakukan terapi relaksasi progresif $(\mathrm{p}=$ 0,000).

Pemberian kombinasi antara terapi thought stopping dengan relaksasi progresif dapat memberikan dampak positif terhadap respon pasien secara kognitif dan fisiologis untuk melatih tubuh mengalihkan diri rangsangan dari dalam atau dari luar individu. Pada relaksasi progresif terhadap relaksasi otot akan menghambat jalur tersebut dengan cara mengaktivasi sistem saraf parasimpatis dan manipulasi hipotalamus melalui pemusatan pikiran atau memperkuat sikap positif dan untuk membantu pasien mengubah proses berpikir sedangkan terapi thought stopping untuk merubah proses pikir yang terganggu. Kombinasi terapi thought stopping, relaksasi progresif dan psikoedukasi sangat efektif diberikan pada pasien ansietas. Pasien dapat merubah pikiran yang negatif dengan cara melakukan gerakan meregangkan dan melemaskan pada sejumlah otot sehingga aliran darah pada semua sistem menjadi lancar dan pada akhirnya akan mengurangi gangguan fisiologis pasien. Dukungan keluarga akan membantu mempercepat penyembuhan pasien, dengan psikoedukasi keluarga akan mampu mengatasi ansietas baik ke pasien maupun ke 
keluarga. Respon fisiologis pasien ansietas setelah diberi terapi thought stopping, relaksasi progresif dan psikoedukasi berubah pada gangguan tidur, gejala gangguan pola tidur dan makan, sedangkan pada keluhan pasien pusing sudah masih ditemukan. Respon afektif pasien ansietas masih merasa khawatir, bingung dan tidak berdaya masih ditemukan.

Respon fisiologis yang ditemukan pada kasus spesialis khususnya diagnosa ansietas adalah peningkatan tekanan darah, terganggunya pola tidur, gangguan makan dan sakit kepala. Respon fisiologis pada kasus ditemukan pasien mengalami gangguan tidur. Respon fisiologis saat stres merefleksikan interaksi beberapa neuroendokrin yang meliputi hormon, prolaktin, hormon adrenokortikotropik (ACTH) vasopresin, oksitosin, insulin, epineprin, norepineprin, dan neurotransmiter lain di otak. Respon fisiologis fight-or-fligh menstimulasi divisi simpatik dari sistem saraf autonomik dan meningkatkan aktivitas kelenjar adrenal. Sebagai tambahan, stres dapat mempengaruhi sistem imun dan mempengaruhi kemampuan seseorang untuk melawan penyakit.

Hasil penelitian Endriyani et al., (2019) penelitian ini adalah quasy experiment prepost test with control group dengan intervensi relaksasi progresif. Penelitian dilakukan untuk mengetahui perbedaan tingkat kecemasan pada pasien hipertensi sebelum dan sesudah diberikan perlakuan berupa relaksasi progresif. Ada hubungan yang signifikan antara lamahipertensi dengan tingkat kecemasan responden. Pada kejadian kecemasan penderita hipertensi, respon fisiologis terjadinya stres terutama pada sistem kardiovaskular, stimulasi adrenergik mengakibatkan vasokonstriksi perifer dan peningkatan tekanan darah sistemik. Terdapat penurunan tingkat kecemasan pasien hipertensi di Puskesmas Makrayu lebih besar pada kelompok yang intervensi yang mendapatkan terapi relaksasi progresif daripada kelompok kontrol.

\section{SIMPULAN}

Karakterisktik pasien yang mengalami ansietas di ruang hemodialisa lantai 3 Rumah Sakit Pelni Jakarta meliputi usia rata-rata dewasa lebih dari 41 tahun, jenis kelamin sebagian besar perempuan, pekerjaaan ibu sebagian besar ibu rumah tangga, pendidikan rata-rata menengah (SMA) dan status perkawinan menikah. Faktor predisposisi penyebab ansietas pada pasien yang banyak ditemukan adalah pada aspek biologis akibat penyakit kronis, aspek psikososial sedih dan khawatir, dan pada aspek sosial budaya yaitu pekerjaan pasien yang kurang memadai.

Hasil pelaksanaan paket terapi keperawatan yang efektif diberikan pada skala ringan adalah terapi generalis dan terapi spesialis thought stopping, relaksasi progresif dan psikoedukasi dengan hasil kemampuan pasien mengontrol ansietas meningkat serta berdampak positif terhadap caregiver.

\section{SARAN}

Perlunya pengembangan pelayanan CLMHN yang diterapkan di seluruh ruangan di unit pelayanan umum. Perlunya seorang liaison nurse yang ditempatkan di unit pelayanan umum dalam rangka memberikan pelayanan kesehatan jiwa yang holistik terhadap seluruh sistem pasien. Pelayanan keperawatan membuat kebijakan terkait dengan program pelayanan keperawatan spesialistik khususnya untuk membuat standar keperawatan terkait dengan pelaksanaan manajemen kasus psikososial pada pasien dan keluarga. Menciptakan lingkungan tenang untuk meningkatkan efektifitas intervensi keperawatan yang dilakukan 
dengan memasang sampiran, memilih waktu yang tepat saat pemberian terapi. Bekerjasama dengan perawat ruangan untuk meningkatkan pemberian asuhan keperawatan yang komprehensif.

\section{DAFTAR PUSTAKA}

Endriyani, S., Pome, G., \& Rizal, F. (2019). Pengaruh Teknik Relaksasi Progresif terhadap Penurunan Tingkat Kecemasan pada Pasien Hipertensi di Puskesmas Makrayu Palembang. Jurnal Keperawatan Sriwijaya, 6(2), 1-6. https://ejournal.unsri.ac.id/index.php/jk_sriwijaya/article/download/9659/4931

Hidayat, E. (2018). Pengaruh Terapi Relaksasi Progresif terhadap Penurunan Tingkat Kecemasan dalam Menghadapi Uji Kompetensi Mahasiswa Tingkat III Akper Muhammadiyah Cirebon. Jurnal Keperawatan Soedirman, 12(2), 93. https://doi.org/10.20884/1.jks.2017.12.2.740

Kamil, I., Agustina, R., \& Wahid, A. (2018). Gambaran Tingkat Kecemasan Pasien Gagal Ginjal Kronik yang Menjalani Hemodialisis Di RSUD Ulin Banjarmasin. Dinamika Kesehatan, 9(2), 366-377. https://ojs.dinamikakesehatan.unism.ac.id/index.php/dksm/article/view/350

Livana, P., Susanti, Y., \& Rahmawati, D. (2019). Gambaran Tingkat Ansietas Pasien dan Keluarga Pasien Hemodialisis. Jurnal Keperawatan Jiwa, 5(1), 10. https://doi.org/10.26714/jkj.5.1.2017.10-13

Neuen, B. L., Chadban, S. J., Demaio, A. R., Johnson, D. W., \& Perkovic, V. (2017). Chronic Kidney Disease and the Global NCDs Agenda. In BMJ Global Health (Vol. 2, Issue 2). https://doi.org/10.1136/bmjgh-2017-000380

Rini, A. S., \& Suryandari, D. (2019). Asuhan Keperawatan Pasien Chronic Kidney Disease (CKD) dalam Pemenuhan Kebutuhan Rasa Aman dan Nyaman: Ansietas. Stikes Kusuma Husada Surakarta

Riskesdas. (2018). Hasil Utama Riset Kesehatan Dasar. Kementrian Kesehatan Republik Indonesia, 1-100. https://doi.org/1

Rizqiea, N. S., Munawaroh, M., Hapsari, H. I., \& Ekacahyaningtyas, M. (2017). Terapi Murottal dan Kualitas Hidup Pasien Gagal Ginjal Kronik dengan Hemodialisa di RSUD dr. Soediran Mangun Sumarso Wonogiri. Adi Husada Nursing Journal, 3(2), 65-69

Siswoyo, B. S., \& Holil, A. (2016). Terapi Psikoedukasi Menurunkan Kecemasan Keluarga dalam Merawat Anggota Keluarga yang Menderita Katarak. NurseLine, 1(2), 237245

Suryani, S., Widianti, E., Hernawati, T., \& Sriati, A. (2016). Psikoedukasi Menurunkan Tingkat Depresi, Stres dan Kecemasan pada Pasien Tuberkulosis Paru. Jurnal Ners, 11(1), 128-133. https://media.neliti.com/media/publications/119206-ID-none.pdf

Syisnawati, S., Keliat, B. A., \& Putri, Y. S. E. (2017). Penerapan Terapi Relaksasi Otot Progresif pada Klien Ansietas di Kelurahan Ciwaringin Bogor. Journal of Islamic Nursing. https://doi.org/https://doi.org/10.24252/join.v2i2.3983

Widiyati, S. (2016). Hubungan antara Kecerdasan Spiritual dengan Tingkat Kecemasan Pasien Gagal Ginjal Kronik yang Menjalani Hemodialisa di Bangsal Teratai RSUD dr. Soedirman Mangun Sumarso Wonogiri. Stikes Kusuma Husada Surakarta 
Wijaya, A. K., \& Padila, P. (2019). Hubungan Dukungan Keluarga, Tingkat Pendidikan dan Usia dengan Kepatuhan dalam Pembatasan Asupan Cairan pada Klien ESRD yang Menjalani Terapi Hemodialisa. Jurnal Keperawatan Silampari, 3(1), 393-404. https://doi.org/https://doi.org/10.31539/jks.v3i1.883

World Health Organization. (2017). Global Status Report on Noncommunicable Disease 2013 